\title{
STRATEGIC ALLIANCES IN AIRLINE BUSINESS: COMPARISON OF SKYTEAM, ONEWORLD, STAR ALLIANCE GROUPS
}

\author{
Sabiha ANNAÇ GÖV ${ }^{1}$
}

\begin{abstract}
Strategic alliance is the common use of resources and core competences by the enterprises in the production, distribution and development of goods and services in order to gain a competitive advantage in the sector. By using strategic collaboration techniques, airline companies can provide advantages such as economic, financial and managerial development, expansion of flight networks and increasing market share. Collaboration applications reduces the transfer and waiting times of passengers, provides more flight options, provides rewards for frequent flying passengers, provides reservation priority and standardized service. In this study, strategic cooperation techniques are explained; the quantity and qualifications of the Star Alliance, Skyteam and Oneworld alliances, which are strategic cooperation organizations, were compared according to many criteria such as number of members, annual income, market share, destination, daily flight. It was determined that the Star Alliance is advanced in terms of quantity and quality.
\end{abstract}

Key words: Aviation Management, Strategic Management, Strategic Alliances, Airline Collaborations.

JEL Codes: L93, M16, L1, P13, N70.

Başvuru: 04.10.2019

Kabul: 29.01.2020

\section{HAVAYOLU İŞLETMELERINDE STRATEJIKK IŞBIIRLİKLERİ: SKYTEAM, ONEWORLD, STAR ALLIANCE GRUPLARININ KARŞILAŞTIRILMASI}

$\ddot{O} z$

Stratejik işbirliği, işletmelerin sektörde rekabetçi bir üstünlük elde edebilmek için mal ve hizmetin üretimi, dağıtımı ve geliştirilmesi konularında kaynaklarını ve $\ddot{o z}$ yeteneklerini ortaklaşa kullanmalarıdır. Havayolu şirketleri stratejik işbirliği tekniklerini kullanarak ekonomik, finansal ve yönetimsel açıldan gelişme, uçuş ağlarını genişletme ve pazar payını arttırma gibi avantajlar sağlayabilmektedirler. İ̧̧birliği uygulamaları; yolcuların aktarma ve bekleme sürelerini azaltmakta, daha fazla uçuş seçeneği sunmakta, sürekli ve sık uçan yolculara ödüller kazandırmakta, rezervasyon önceliği sağlamakta ve standartlaştırılmış hizmet sunma olană̆l yaratmaktadır. Bu

1- Dr. Öğr.Üyesi. Gaziantep Üniversitesi, Havacılık ve Uzay Bilimleri Fakültesi, Havacılık Yönetimi Bölümü,sgov@gantep.edu.tr Orcid: 0000-0001-7601-559X 
çalışmada stratejik işbirliği teknikleri açıklanmış; stratejik işbirliği örgütleri olan Star Alliance, Skyteam ve Oneworld ittifaklarının nicelik ve nitelikleri üye sayısl, yıllık gelir, pazar payl, destinasyon, günlük uçus gibi birçok kritere göre karşılaştırılmıştır. Star Alliance ittifakının nicelik ve nitelik bakımından ileri seviyede olduğu belirlenmiştir.

Anahtar Kelimeler: Havacılı Yönetimi, Stratejik Yönetim, Stratejik İttifaklar, Havayolu Işbirlikleri.

JEL Kodları: L93, M16, L1, P13, N70.

'Bu çalışma Araştırma ve Yayın Etiğine uygun olarak hazırlanmıştır.'

\section{INTRODUCTION}

In today's economy, chance of companies' competing with their own resources and surviving alone is decreasing day by day. The advancement in information technology and communication and the realization of economic activities without national border have made companies open to the competition of all kinds of companies from all over the world. Even the largest and strongest companies are trying to use their resources more efficiently and to increase their competitiveness through mergers and strategic alliances. Until 1980, the International Air Transport Organization (IATA) has strictly adhered to airline service standards. Until this period, the rules of airline management, which had strict rules, gained momentum with the movement of liberalization. After the $80 \mathrm{~s}$, a new structure was created with the effect of liberalization in the airline sector and competition increased with the increase of the actors in air transport. Airline companies have entered into a process of cooperation and integration in order to get more shares from national and international markets and increase their competitiveness. According to Gudmundsson and Rhoades (2011), reducing costs is considered to be one of the most important driving forces for airlines to become members of global airline alliances.

The concept of strategy is actually a concept in terms of military and war tactics, but the concept of strategy has also been used in management science. The concept of strategy is defined as military substitution by considering everything carefully. In terms of management science, it can be defined as the guiding decision structures in determining the purpose of the enterprise, its reason of existence or its position in life (Cole, 1993: 102). Strategic cooperation is that enterprises use their resources and their skills in the production, distribution and development of goods and services in order to gain a competitive advantage in the sector.

Strategic partnerships considered as bilateral or multiple agreements; It can be seen that the enterprises bring their services together in a coordinated way for the common purpose. Doganis (2006) stated that components such as common brand, standardization of services, personnel and terminal facilities are the driving factors in strategic partnerships. Cravens et al., (1993: 55) defines strategic alliance is a tool to gain a competitive advantage in a product or in a market of the organization when environmental turbulence and diversity is high and the organization's skills and resource gaps are high, On the other hand, Spekman and Sawhney (1990: 90) have defined a strategic alliance as a collaborative relationship type, that "partners make significant investments to develop individual orientations towards a long-term collaborative effort and common goals". 


\subsection{Literature Review}

Several recent studies about comparison of strategic alliances were discussed in this section. Min \& Joo (2016) compared the performance of strategic alliances in the airline business. According to their study, joining an alliance does not certainly improve comparative activity efficiency for big airlines, but smaller alliances carry out better than the larger one. Alliance membership is not either positively or negatively associated with airline efficiency. So, airlines participating in an alliance group is enhancing their technical and scale efficiency seems vague.

Wang (2014) mentioned that airlines can affect consumer purchase intention by enhancing the customer perception of brand equity and brand preference by joining a global airline alliance. But product differentiation has become increasingly substantial, because of competition among airlines has led to the saturation of global airline alliances.

Kottas and Madas (2018) founded that alliance group membership is not associated with superior airline efficiency by implementing Data Envelopment Analysis (DEA) to assess the effect of alliance group membership on 30 major international airlines regarding period 2012-2016. In addition, they found that airlines with high freight traffic revenue share are more efficient than airlines demonstrating lower freight traffic revenue share. Furthermore, they mentioned that a statistically significant superior efficiency of Asian and European air carriers over American air carriers.

Tunahan et all. (2016) performed the comparative analysis of financial risk levels, measured over their financial ratios of the world's three largest global airline alliances (Star Alliance, Oneworld and Skyteam); which sell cheap tickets through low cost strategy by performing fuzzy logic method. They found that in terms of financial risk levels for the period of 2010-2014 there is no difference between alliances and low-cost airlines. However, the second analysis showed that there is difference between alliances and low-cost airlines in terms of financial risk levels.

Kiraci (2019) found that airline' liquidity, debt and profitability performances differed before and after membership to global alliances. According to his study Lufthansa has a good performance before joining global alliances. However, Lufthansa became fourth in financial performance after becoming a member of the global alliance. He found that the financial performance of Air New Zealand changed significantly after joining alliance.

Kazakova et all. (2018) conducted a research that helps in systematizing the most specific advantages received by the companies from participation in the alliance. This research can be divided into qualitative and quantitative. By using common loyalty program for customers, etc. quality benefits increase the attractiveness of the services of alliance members, such as an image strengthening and brand development, decrease in the risk of business due to the weakening of competition in the market.

As seen in the literature, the effects of participation were investigated more than the comparison of strategic alliances. So, this situation can be accepted as a research gap. In this study, topics such as code sharing, frequent flight agreement, pool agreement, partnership, block booking, commercial agreements, special proration agreement, which are known as types of cooperation in aviation market, will be clarified. A comparison of the three groups will be made by giving information about Skyteam, Star Alliance 
and Oneworld alliances which are among the leading strategic cooperation groups in the airline sector.

The objective of this research is to investigate members of alliances by presenting members' current annual passengers, fleet, revenue, serviced countries etc. Some investigations were made about strategic alliances by other researchers. Major contributions of this study include literature survey about airline alliances and current situation of strategic airline alliances. This research presents comparison of three biggest alliances by evaluating studies that in literature.

\subsection{Causes of Strategic Collaboration}

The airline companies are merging with the aim of eliminating the negativities caused by being independent and increasing their activities. Thanks to the cooperation, airline operators have the opportunity to evaluate by combining the elements which are the capital, labour force, technology, education techniques and tools that they cannot use efficiently via alone, and they operate more effectively.

The reasons for the rapidly increasing airline mergers are as follows (Mühim, 2012):

- To increase their management skills and to create synergies in terms of both business and financial

- Extending fixed cost costs to a wider production volume by reducing production costs per unit and benefiting from economies of scale

- To diversify its products, customers and markets, to benefit from tax and structural advantages, to keep up with global changes

-To acquire the power of the market, borrow from interest rates below the market, make more use of technological developments

- The desire to preserve the company's position in the market, the desire to establish superiority in the market, to take psychological advantage versus becoming obsolete or retreat.

Participation of Turkish Airlines to the Star Alliance in 2006 has made structural change in firms' profitability. So, the current ratio and asset turnover rate of Turkish Airlines between 1992-2013 is modelled on return on equity. Membership of Turkish Airlines to the alliance has resulted a structural change on firm's return on equity (İlarslan et all, 2014:111). This shows one of the reasons for joining to alliance.

\section{STRATEGIC COLLABORATION APPLICATIONS}

Strategic collaboration is the common use of resources and core competences by the enterprises in the production, distribution and development of goods and services in order to gain a competitive advantage in the sector. The aim of strategic cooperation is to create new value by creating synergy in production, R \& D and marketing (Sumer, 2003: 210).

The airline companies cooperate and develop in economic, financial and managerial terms, expanding their flight network and increasing their market share. It is aimed to make sectoral developments faster by using different types of cooperation arrangements 
in air transport. The most common types of cooperation in airlines are code-sharing, frequent flyer, joint venture, pool agreement, and marketing collaboration methods.

\subsection{Code-Sharing Agreement}

Code sharing is the simplest application used in airline collaboration and its main purpose is to combine flight networks. In this type of cooperation, the flight schedules of the two airlines are organized in a coordinated manner. In the code sharing agreement, the transfer time of passengers and baggage is shortened and the loss of time is prevented because there is no waiting for transfer (Rajasekar and Fouts, 2009: 94).

Code-sharing airline companies use a common code, although their flights are different, they give a single flight code to the transfer flights between the two cities; Thus, they show the flight as a direct flight. In this way, passengers reach where they want to go in a shorter time and easily without any delay (Shweiger and Philippe, 2003: 14). Code sharing increases the commercial importance of airports and planned routes in global airline alliance networks.

In the study of Klophaus and Lordan (2018), the strategic cooperation groups were compared in terms of code sharing and the Oneworld group was found to be the most vulnerable. This means that the code sharing network will be most affected and damaged by the separation of a member company from the group. Skyteam can be less affected; Star Alliance is the least affected alliance organization. Star Alliance is seen as a collaborative partnership that offers the most robust code sharing against devastating events such as extreme weather events, strikes or terrorist threats.

Code sharing agreements are important because the flights of the member airlines appear direct flights. Code sharing provides many advantages for airline transport companies and passengers and brings along some disadvantages. Two airlines with different service quality are seen as disadvantages of customer satisfaction, catering and ground handling problems (Flights of fancy, 2015: 22).

\subsection{Frequent Flyer Program Agreement}

The frequent flight program agreement is an agreement made by airline operators to encourage passengers to fly more often with the same company by offering some prizes and opportunities. The main purpose of the airline transport companies, which frequently conducts frequent flight programs, is to create brand image and to increase their market share and revenue by awarding airline passengers frequently (Evans, 2001: 230).

Airline companies can set up three different flight classes: economy class, business class, and first class. While making these tariffs, strategies are created for each of the three classes and different services are offered. Passengers traveling for business travel more often. Frequent flight programs which increase the satisfaction and loyalty of frequent flying passengers and the company's frequent flight programs to business people who travel frequently are presented many awards like as free tickets, holidays and so on (Evans, 2001: 240). Usage Credit card such as Smart Card given to frequent flight program members decreases the waiting time of passengers and increases automation in ground services. 


\subsection{Pool Agreements}

Airline companies often compete with at least one airline in each international flight. The two airlines share the revenues and expenses arising from the reciprocal flights in the pool agreements and jointly carry out the flight activities. Since the airline companies are in competition, the flight schedules are determined according to the intensity of the demand, and each company organizes several flight programs at the same flight point and at the same time. That many airlines fly to the same spot at the same time is reducing their occupancy rates and thus the costs are increasing. With the pool agreements, the number of passengers in an airplane is increased and costs are reduced by making common arrangements in flight frequency and flight tariffs of firms (Brekalo and Albers, 2016: 235).

The pool agreement has advantages in terms of passengers and the company. While the cost of companies is decreasing, passengers have the opportunity to get cheap but high quality service. The disadvantage of pool agreements is that the enterprises which are not in the pool of agreement face the destructive effect of competition.

\subsection{Marketing Agreements}

One of the most common types of cooperation in recent years is the marketing agreement. In particular, the expansion of information technologies and the increase of digital reservation and ticket sales systems have spread marketing agreements. Computerized reservation systems increase the occupancy rates of air transport companies at low cost, enable effective marketing at low cost and increase their market share (Elmuti and Kathawala, 2001: 215).

The main purpose of digital reservation systems and global distribution systems is the data on flights, seats and prices that can be controlled by airlines. With the loading of these data, it is possible to monitor the sales made through travel agents from the head office. (Glisson et al., 1996: 30).

Computerized reservation systems in the airline market have many advantages, but also cause some disadvantages. Companies outside computerized reservation systems are dependent on multinational companies to provide their services. In addition, the staff may be injured in the reservations due to errors in the determination of the fare and class. Further computerized reservation systems, monopolized structures in some regions can lead to a destructive competition.

\subsection{Joint Venture}

Joint Venture can be defined as an agreement that will restrict the parties to which two or more companies are required to perform a project together or to sign an economic activity (Dayındarl1, 2007: 53). Joint venture is simpler than merger and more comprehensive legal and economic formation than cooperation agreements. This type of collaboration is usually created to realize different economic activities such as $\mathrm{R} \& \mathrm{D}$, marketing and distribution. Companies that sign a contractual partnership agreement share the profit, while at the same time they bear the risk and loss jointly (Grunow, 2012:434).

Local airline traffic in the USA constitutes $40 \%$ of the world's air traffic (FAA, 2018). In 
other words, approximately half of the airline traffic is in the USA. The basis of partnership agreements in the airline industry is based on the purpose of building a bridge between the United States and Europe. Using the advantages of large-scale partnerships, airline companies can also catch up with the common market research, marketing, distribution channels, product diversification, and long-term global airline companies (Elmuti and Kathawala, 2001: 215).

\subsection{Blockspace Agreement}

One of the two airlines to reserve seats or cargo from one flight to another is called a block booking agreement. If the cost of arranging flight schedules to any location due to insufficient demand, the seats of another airline company are sold and costs are reduced. With the block booking agreement, while the costs of the two airline companies are falling, new lines of activity are determined and their fields of activity are expanded (Sobie, 2007: 63).

\subsection{Commercial Agreements}

It is an agreement that allows an air transport company to grant traffic permit to the other airline company and to charge a certain fee per passenger (Glisson et al., 1996: 30). In the case of non-reciprocal travel, commercial agreements benefit the airline of the rightful one, such as to provide income in exchange for its own market share from the one-way airline.

\subsection{Pro-rate agreement}

The special proration agreement allows the airline company to transfer passengers to each other's flights by making a deal with another firm operating on that line, in exchange for a fixed fee or commission (Ratliff and Weatherford, 2013: 28). Thanks to special proration agreements, the airline company is able to reach the points where it does not fly, expand its potential market and create additional passenger capacity. For example, a proration agreement was made between Turkish Airlines and Virgin America in 2013. Thanks to this deal, passengers traveling to America made it possible to travel to Los Angeles via the Virgin America flights to 31 destinations, including San Francisco, Portland, Seattle, Dallas, Fort Worth, and Cancun (airporthaber, 2013).

\section{RESEARCH METHOD}

Descriptive research method was used in this study. this method is preferred by many researchers since the researches can be carried out without disturbing the natural conditions in the examination process or making any changes in the examined environment (Çepni, 2010). Descriptive studies are mostly cross-sectional studies. Studies that involve observing a case or sample at a certain time are called cross-sectional studies. The main limitation of cross-sectional research is that they have only one historical context. (Earl, McCarthy, \& Soule, 2004: 101). The sample of the research consists of Skyteam, Staralliance and Oneworld member companies. Corporate websites of airline companies that are members of the airline collaborations included in the sample were analyzed with a descriptive survey model. The model; It is a research method that aims to describe a 
situation that exists in the past or still as it exists (Karasar, 2007: 77). In this study, the descriptive characteristics (membership date, number of employees, income, number of fleets) of companies that are members of strategic collaborations are presented in tables and comparisons are made.

\section{RESULTS}

Over the years, national and private air transport companies have been operating under IATA (International Air Transport Organization) rules for service and ticket fees. The fact that the airline companies are fully dependent on IATA rules, the airline companies' ticket prices, flight lines, working conditions and service types have been determined by IATA, has led to the formation of oligopoly in the airline sector. Today, airline companies use code sharing agreements and frequent flight programs. The most important reason for this is that both methods are easy to implement and do not bring any additional cost to airlines. In this way, airline companies expand their flight network and increase the number of passengers they carry, without investing in additional costs. Strong and large airline companies have established airline carriers called mega carriers by buying small airlines.

The spread of global distribution systems and the use of computerized reservation systems developed for air transport companies have resulted in large groups of partners. The most important and conspicuous of these alliance groups are Star Alliance, Oneworld and Skyteam (Czipura and Jolly, 2007: 60).

\subsection{Star Alliance}

Star Alliance, founded in 1997 by six major airlines such as Air Canada, Lufthansa, Scandinavian Airlines (SAS), Thai Airways, United Airlines and Varig Airlines, has been a pioneer for other partnerships and alliances. Air New Zealand, All Nippon Airways, Ansett Australia, British Midland, Mexicana Airlines, Singapore Airlines and Turkish Airlines also joined the group. It has 28 members (Star Alliance, 2018). Members of Star Alliance are showed in Table 1.

Table 1. Members of the Star Alliance (Star Alliance, 2018)

\begin{tabular}{|c|c|c|c|c|c|c|c|}
\hline Airline & Country & $\begin{array}{l}\text { Member } \\
\text { Since }\end{array}$ & $\begin{array}{l}\text { Fleet } \\
\text { Size }\end{array}$ & $\begin{array}{l}\text { Total } \\
\text { revenue }\end{array}$ & $\begin{array}{l}\text { Number of } \\
\text { employes }\end{array}$ & $\begin{array}{l}\text { Countries } \\
\text { served }\end{array}$ & $\begin{array}{l}\text { Annual } \\
\text { passenger }\end{array}$ \\
\hline Adria & Slovenia & $09 / 2004$ & 21 & $\begin{array}{l}0.164 \text { Bil } \\
\text { Usd }\end{array}$ & 493 & 17 & $\begin{array}{l}0.98 \\
\text { million }\end{array}$ \\
\hline Aegean & Greece & $06 / 2010$ & 46 & 1.12 & 2285 & 44 & $7.37 \mathrm{mil}$ \\
\hline Air Canada & Canada & Founder & 390 & 12.52 & 32000 & 61 & $48 \mathrm{mil}$ \\
\hline Air China & China & $12 / 2007$ & 397 & 5.99 & 29429 & 42 & 33.14 mil \\
\hline Air India & India & $07 / 2014$ & 125 & 3.3 & 10411 & 28 & $24.6 \mathrm{mil}$ \\
\hline $\begin{array}{l}\text { Air New } \\
\text { Zealand }\end{array}$ & $\begin{array}{l}\text { New } \\
\text { Zealand }\end{array}$ & $03 / 1999$ & 112 & 3.9 & 12000 & 17 & $17 \mathrm{mil}$ \\
\hline ANA & Japan & $10 / 1999$ & 266 & 18.5 & 13928 & 22 & $53.9 \mathrm{mil}$ \\
\hline $\begin{array}{l}\text { Asiana } \\
\text { Airlines }\end{array}$ & South Korea & $03 / 2003$ & 84 & 5.374 & 11634 & 22 & $19.5 \mathrm{mil}$ \\
\hline Austrian & Austria & $03 / 2003$ & 83 & 2.47 & 6914 & 57 & $12.9 \mathrm{mil}$ \\
\hline
\end{tabular}




\begin{tabular}{|l|l|l|l|l|l|l|l|}
\hline Avianca & Colombia & $06 / 2012$ & 189 & 4.4 & 19000 & 27 & 29.4 mil \\
\hline $\begin{array}{l}\text { Brussels } \\
\text { Airlines }\end{array}$ & Belgium & $12 / 2009$ & 54 & 1.557 & 4000 & 54 & $9.1 \mathrm{mil}$ \\
\hline $\begin{array}{l}\text { Copa } \\
\text { Airlines }\end{array}$ & Panama & $06 / 2012$ & 102 & 2.53 & 9204 & 32 & $13.3 \mathrm{mil}$ \\
\hline $\begin{array}{l}\text { Croatia } \\
\text { Airlines }\end{array}$ & Croatia & $12 / 2004$ & 12 & 0.276 & 1102 & 19 & $2.13 \mathrm{mil}$ \\
\hline Egypt Air & Egypt & $07 / 2008$ & 69 & 1.57 & 9000 & 47 & $7.33 \mathrm{mil}$ \\
\hline $\begin{array}{l}\text { Ethiopian } \\
\text { Airline }\end{array}$ & Ethiopia & $12 / 2011$ & 108 & 3.32 & 16732 & 75 & $10.63 \mathrm{mil}$ \\
\hline EVAAir & Taiwan & $06 / 2013$ & 79 & 4.10 & 10950 & 18 & 12 mil \\
\hline $\begin{array}{l}\text { LOT Polish } \\
\text { A. }\end{array}$ & Poland & $10 / 2003$ & 75 & 1.51 & 1690 & 50 & 9 mil \\
\hline Lufthansa & Germany & Founder & 357 & 20.16 & 37500 & 76 & $66.2 \mathrm{mil}$ \\
\hline $\begin{array}{l}\text { Scandinavian } \\
\text { A. }\end{array}$ & Sweden & Founder & 156 & 5.20 & 10261 & 30 & 30 mil \\
\hline $\begin{array}{l}\text { Shenzhen } \\
\text { Airlines }\end{array}$ & China & $11 / 2012$ & 191 & 3.86 & 25304 & 7 & $30.22 \mathrm{mil}$ \\
\hline Singapore A. & Singapore & $04 / 2000$ & 112 & 8.51 & 14765 & 32 & $19.51 \mathrm{mil}$ \\
\hline $\begin{array}{l}\text { South } \\
\text { African A. }\end{array}$ & $\begin{array}{l}\text { South } \\
\text { Africa }\end{array}$ & $04 / 2006$ & 48 & 2.0 & 5752 & 22 & $6.8 \mathrm{mil}$ \\
\hline Swiss & Switzerland & $04 / 2006$ & 90 & 5.0 & 8834 & 43 & $16.9 \mathrm{mil}$ \\
\hline TAP Portugal & Portugal & $03 / 2005$ & 91 & 3.46 & 7470 & 34 & $14.2 \mathrm{mil}$ \\
\hline Thai & Thailand & Founder & 100 & 5.73 & 22370 & 31 & $25 \mathrm{mil}$ \\
\hline $\begin{array}{l}\text { Turkish } \\
\text { Airlines }\end{array}$ & Turkey & $04 / 2008$ & 329 & 9.40 & 24075 & 122 & $68.6 \mathrm{mil}$ \\
\hline United & $\begin{array}{l}\text { United } \\
\text { States }\end{array}$ & Founder & 1306 & 40.3 & 90900 & 48 & $156 \mathrm{mil}$ \\
\hline
\end{tabular}

The main purpose of the Star Allience is to create a homogeneous product with the common system that allows each airline to recognize the flight program, to provide quality goods and services to its passengers and to establish a global communication network covering many countries of the world.

Star Alliance has established a global communication network that provides many services ranging from frequent flight schedules to uninterrupted travel to international travellers. With a network of more than 192 countries in the world and more than 1330 destinations around the world, the network offers a global network that easily meets passengers' ticketing or booking requests and offers the opportunity to travel anywhere in the world. Star Alliance offers frequent flyer program rewards, which offer deals such as price reductions or free tickets on flights with any member of the airline. The elite passengers who receive the gold membership of the Star Alliance can use the comfortable and luxurious waiting lounges and benefit from all kinds of services in more than 1000 airports around the world. Especially with open tickets given to businessmen, changes can be made to the airport or airline ticket sales branches without any need to change the destination and date, and it is possible to fly with any Star Alliance member and to postpone the ticket. By signing a global product agreement, Star Alliance members can get support for all travel organizations and standardized products in all member airline 
companies and around the world. The product guarantee is provided to the passengers with the global product agreement application and the problems caused by the company difference are generally eliminated (Star Alliance,2018).

Star alliance members increase the number of passengers and the number of passengers they carry by making code sharing, frequent flight program, pool agreements and decrease their costs. Passengers of member companies have many advantages such as quality service, low price and mileage. As a result of these advantages, it is possible to work profitably and efficiently; there is a competitive advantage against other alliances (Czipura and Jolly, 2007: 60).

In general, the Star Alliance group offers many advantages such as flying to new destinations, protecting against negative effects of competition, creating effective and efficient work, creating financing opportunities and providing ease of marketing and continues to develop with new services. However, for the sustainability of success, it is necessary to remove the differences between airline companies, to balance the quality of service and to standardize.

Within the scope of social responsibility, the Star Alliance group has emphasized economic sustainability, climate and environmental responsibility, corporate citizenship, but does not mention specific studies as an alliance, and member enterprises are working on what individual sustainability studies are.

\subsection{Oneworld Alliance}

Oneworld, which was established in 1999 between American Airlines, British Airways, Quantas Airlines, Cathay Pasific, Finnair, Iberia and Lanchile airlines, has aimed to provide services to passengers all over the world. Oneworld, consisting of 15 members, provides access to 1016 destinations in 151 countries and provides all necessary services to passengers (Oneworld, 2018). Oneworld members consist of 13 airlines as shown in the table below. In addition, Oneworld Airline Affiliates and Oneworld Connect provide support for the association to work actively. Therefore, it is accepted as 15 members. It can be seen on table 2 as 13 members. Oneworld 's member airlines offer more than 650 private waiting rooms in different parts of the world, offer the opportunity to benefit from rest and other services in waiting rooms to passengers especially those who are frequent flight program members. Passengers may be privileged with the American Airlines' Advantage, the Executive Club of British Airlines, the Marco Polo Club of Cathay Pasific and the frequent flyer program award of Finair Plus, Quantas Frequent Flyer and Iberia Plus (Czipura and Jolly, 2007: 60; oneworld, 2018). 
Table 2. Members of the Oneworld

\begin{tabular}{|c|c|c|c|c|c|c|c|}
\hline Airline & Country & $\begin{array}{l}\text { Member } \\
\text { Since }\end{array}$ & $\begin{array}{l}\text { Fleet } \\
\text { Size }\end{array}$ & $\begin{array}{l}\text { Total } \\
\text { revenue }\end{array}$ & Employes & $\begin{array}{l}\text { Country } \\
\text { served: }\end{array}$ & $\begin{array}{l}\text { Annual } \\
\text { passenger }\end{array}$ \\
\hline $\begin{array}{l}\text { American } \\
\text { Airlines }\end{array}$ & $\begin{array}{l}\text { United } \\
\text { States }\end{array}$ & Founder & 956 & $\begin{array}{l}44.54 \text { bil } \\
\text { usd }\end{array}$ & 104.400 & 50 & $203.7 \mathrm{mil}$ \\
\hline $\begin{array}{l}\text { British } \\
\text { Airways }\end{array}$ & $\begin{array}{l}\text { United } \\
\text { Kingdom }\end{array}$ & Founder & 275 & $\begin{array}{l}13.020 \\
\text { mil gbp }\end{array}$ & 45000 & 80 & $\begin{array}{l}44.142 \\
\text { mil }\end{array}$ \\
\hline $\begin{array}{l}\text { Cathay } \\
\text { Pacific }\end{array}$ & $\begin{array}{l}\text { Hong } \\
\text { Kong }\end{array}$ & Founder & 146 & $\begin{array}{l}97.284 \\
\text { mil }\end{array}$ & 33,000 & 30 & $34.8 \mathrm{mil}$ \\
\hline Finnair & Finland & 09/1999 & 79 & $2,568 \mathrm{mil}$ & 6462 & 30 & $12 \mathrm{mil}$ \\
\hline Iberia & Spain & $09 / 1999$ & 85 & $\begin{array}{l}340 \\
\text { million }\end{array}$ & 7300 & 47 & 19 mil \\
\hline $\begin{array}{l}\text { Japan } \\
\text { Airlines }\end{array}$ & Japan & $04 / 2007$ & 164 & 53.516 bil & 33000 & 20 & $34.8 \mathrm{mil}$ \\
\hline Latam & Chile & $06 / 2000$ & 313 & $\begin{array}{l}8.494 \text { bil } \\
\text { Usd }\end{array}$ & 40000 & 23 & 50 mil \\
\hline $\begin{array}{l}\text { Malaysia } \\
\text { Airlines }\end{array}$ & Malaysia & $02 / 2013$ & 80 & $4.851 \mathrm{mil}$ & 10,799 & 17 & 75 mil \\
\hline Qantas & Australia & Founder & 127 & 17.6 mil & 33.000 & 20 & 22 mil \\
\hline $\begin{array}{l}\text { Qatar } \\
\text { Airways }\end{array}$ & Qatar & $10 / 2013$ & 220 & 42.229 & 45.633 & 100 & $34.2 \mathrm{mil}$ \\
\hline $\begin{array}{l}\text { Royal } \\
\text { Jordanian }\end{array}$ & Jordan & $04 / 2007$ & 26 & $\begin{array}{l}653.3 \\
\text { million. }\end{array}$ & 4,016 & 40 & $3.3 \mathrm{mil}$ \\
\hline S7 Airlines & Russia & $11 / 2010$ & 91 & $\begin{array}{l}4.4 \text { bil } \\
\text { rubles }\end{array}$ & 3000 & 20 & 15.9 mil \\
\hline $\begin{array}{l}\text { SriLankan } \\
\text { Airline }\end{array}$ & Sri Lanka & $05 / 2014$ & 27 & $\begin{array}{l}126.9 \text { bil } \\
\text { usd }\end{array}$ & 7019 & 48 & $5.5 \mathrm{mil}$ \\
\hline
\end{tabular}

Source: Own presentation by researching web sites of airline corporations.

Oneworld airline companies pay attention to quality service on their flights all over the world; It makes transfers as easy as possible during transfers, especially by providing special services for passengers under protection such as children, disabled and elderly.

Oneworld has classified its work in environmental, human and social terms on sustainability. Oneworld plans to gradually reduce carbon emissions from 2020 to 2050 and plans to reduce noise pollution and fossil fuel dependence. It works philanthropically with UNICEF. At the local level, all members are closely involved with community organizations such as schools, arts and youth groups. It is determined that It helps in extraordinary humanitarian situations. For example, it helped homeless people in Haiti earthquake in 2010, in Japan 2011 earthquake, in Nepal 2015 earthquake (oneworld, 2018). 


\subsection{SkyTeam Alliance}

Established in 2000 and consisting of 20 airlines, SkyTeam aims to provide passengers with a broader transportation network, tariff diversity and easy check-in at airports in 10 countries in 177 countries (SkyTeam, 2018). It can be seen on table 3. SkyTeam aims to increase the share they receive from airline transportation through code sharing agreements and frequent flight programs offered passengers and aims to strengthen the structures of the group members and create competitiveness with the financial support to each other. SkyTeam, known as the world's second largest alliance group, is increasing its number of flights every day.

Table 3. Members of Skyteam Alliance (Skyteam, 2018)

\begin{tabular}{|c|c|c|c|c|c|c|}
\hline Airline & Country & Member Since & $\begin{array}{l}\text { Fleet } \\
\text { Size }\end{array}$ & $\begin{array}{l}\text { Total } \\
\text { revenue }\end{array}$ & $\begin{array}{l}\text { Countries } \\
\text { served }\end{array}$ & $\begin{array}{l}\text { Annual } \\
\text { passenger }\end{array}$ \\
\hline Aeroflot & Russia & $04 / 2006$ & 197 & $\begin{array}{l}427.9 \\
\text { billion }\end{array}$ & 51 & $29 \mathrm{mil}$ \\
\hline $\begin{array}{l}\text { Aerolineas } \\
\text { Argentina }\end{array}$ & Argentina & $08 / 2012$ & 84 & $\begin{array}{l}2.04 \text { bil } \\
\text { (usd) }\end{array}$ & 13 & $11.5 \mathrm{mil}$ \\
\hline Aeromexico & Mexico & Founder & 125 & $\begin{array}{l}53.9 \\
\operatorname{mil}(\mathrm{mxn})\end{array}$ & 24 & 19.6 mil \\
\hline Air Europa & Spain & $09 / 2007$ & 51 & 1.79(eur) & 23 & 10.6 mil \\
\hline Air France & France & Founder & 348 & 24.8 (eur) & 92 & 93.4 mil \\
\hline Alitalia & Italy & $01 / 2009$ & 123 & $\begin{array}{l}3.3 \text { mil } \\
\text { (eur) }\end{array}$ & 41 & $22.6 \mathrm{mil}$ \\
\hline China Airlines & Taiwan & $09 / 2011$ & 98 & $\begin{array}{l}133.4 \\
\text { (twd) }\end{array}$ & 29 & 14.6 mil \\
\hline China Eastern & China & $06 / 2011$ & 581 & $\begin{array}{l}104.2 \text { bil. } \\
(\mathrm{rmb})\end{array}$ & 33 & $101.7 \mathrm{mil}$ \\
\hline China Southern & China & $11 / 2007$ & $702+$ & $\begin{array}{l}114.9 \text { bil } \\
(\mathrm{rmb})\end{array}$ & 40 & $115 \mathrm{mil}$ \\
\hline Czech Airlines & $\begin{array}{l}\text { Czech } \\
\text { Republic }\end{array}$ & $03 / 2001$ & 18 & $\begin{array}{l}7.975 \text { bil } \\
\text { (czk) }\end{array}$ & 25 & $2.7 \mathrm{mil}$ \\
\hline Delta Airlines & $\begin{array}{l}\text { United } \\
\text { States }\end{array}$ & Founder & $800+$ & $\begin{array}{l}40 \text { bil } \\
\text { (usd) }\end{array}$ & 62 & $180 \mathrm{mil}$ \\
\hline $\begin{array}{l}\text { Garuda } \\
\text { International }\end{array}$ & Indonesia & $03 / 2014$ & 196 & $\begin{array}{l}3.86 \text { bil } \\
\text { (usd) }\end{array}$ & 14 & $35 \mathrm{mil}$ \\
\hline Kenya Airways & Kenya & $09 / 2007$ & 36 & $\begin{array}{l}106.2 \text { bil } \\
\text { (kes) }\end{array}$ & 41 & $4.5 \mathrm{mil}$ \\
\hline KLM & $\begin{array}{l}\text { The } \\
\text { Netherlands }\end{array}$ & $09 / 2004$ & 71 & $\begin{array}{l}24.8 \text { bil } \\
\text { (eur) }\end{array}$ & 71 & 30.4 mil \\
\hline Korean Air & South Korea & Founder & 162 & $\begin{array}{l}11.5 \text { tri } \\
(\mathrm{krw})\end{array}$ & 46 & $26.8 \mathrm{mil}$ \\
\hline MEA & Lebanon & $06 / 2012$ & 18 & $\begin{array}{l}1.013 \text { bil } \\
\text { (lbp) }\end{array}$ & 22 & $2.7 \mathrm{mil}$ \\
\hline Saudia & $\begin{array}{l}\text { Saudi } \\
\text { Arabia }\end{array}$ & $05 / 2012$ & 129 & $\begin{array}{l}\begin{array}{l}5.12 \text { bil } \\
\text { (usd) }\end{array} \\
\end{array}$ & 36 & $32.37 \mathrm{mil}$ \\
\hline TAROM & Romania & $06 / 2010$ & 23 & $\begin{array}{l}423 \\
\text { mil(usd) }\end{array}$ & 22 & $2.4 \mathrm{mil}$ \\
\hline
\end{tabular}




\begin{tabular}{|l|l|l|l|l|l|l|}
\hline Vietnam Airlines & Vietnam & $06 / 2010$ & 96 & $\begin{array}{l}62.151 \\
\text { bil(vnd) }\end{array}$ & 17 & 20.6 mil \\
\hline Xiamen Air & China & $11 / 2012$ & 144 & $\begin{array}{l}20.8 \text { bil } \\
\text { (cny) }\end{array}$ & 14 & 25 mil \\
\hline
\end{tabular}

In August 2002, the Alliance launched its service, SkyTeam Europe Pass, aimed at passengers traveling to European destinations, particularly for holiday purposes. This personalized ticketing system has provided a new dimension for SkyTeam passengers to visit different places on the European continent. The SkyTeam Europe Pass provides the convenience and speed, discount prices and extra flight miles for each flight route. SkyTeam added America Pass service In July 2004 and Asia Pass service In October 2005 to the flight network portfolio. Also, SkyTeam incorporates SkyTeam Cargo.

Members have the opportunity to save on costs thanks to the synergy created by the sharing of three or more member airlines in the same area. For example, combining common placement and staff of check-in areas reduces cost of ground services and staff while ensuring efficiency. All common SkyTeam members share services at the airport, from check-in counters, self-service kiosks and luggage delivery areas to SkyTeam's first exclusive check-in area.

Members can obtain a broader brand recognition and exposure, improve market positioning, and increase access to new points; uses Sky Team's structure to increase customer service, cost savings and information sharing. Member brands increase the global presence of the partnership and reinforce brand awareness while reaching the key regions of the world. Through alliance, member airlines benefit from both information sharing and sharing of best practices, especially in security, customer service and operational efficiency. The most important element of SkyTeam's global network is the unique hub and spoke of a unique connection and convenience for customers to reach their destination at any point of the world using their member airlines. The SkyTeam ID represents not only the responsibility of each member airline to the alliance partnership, but also the responsibility to provide high quality service to its customers.

Looking at the corporate social responsibility activities of the SkyTeam alliance, it is seen that it also carries out environmental and social responsibility activities while making a profit. It is stated that there is organizational justice among the employees, and employees are given environmental sustainability awareness training.

\subsection{Comparison of Star Alliance, Oneworld and Skyteam}

According to IATA data; In 2017, 41.8 million flights were performed with 4.1 billion passengers worldwide (IATA, 2018). According to IATA, an important source of data on scheduled air transport in the world; In 2016, a total of 3,810 billion passengers were transported and in 2017 it was reported that it increased by 7,1\% to 4,081 billion. 54.9 million tons of air cargo services were provided. According to 2016 data; If we look at the market share of global airline alliances, Star Alliance is at the top of the list with 23.8 percent. In the second place, SkyTeam took the second place with $20.6 \%$ and Oneworld took a share of $17.8 \%$. Other airlines have been in the market with 37.8 percent (IATA, 2018). According to these data, Star Alliance, Oneworld and Skyteam represented more than $50 \%$ of global capacity. 
If alliances are compared in terms of the number of employees, fleet size (number of aircraft), number of destinations, annual number of passengers, annual income, number of daily flights, and number of countries served, it is seen that the Star Alliance is the most powerful one. In terms of customer satisfaction, Star Alliance is the best in alliances. Compared to the services offered in the three alliances; it is seen that all three of them offer the same services as frequent flyer ease and e-ticket opportunity.

A comparison of Star Alliance, Oneworld and Sky Team alliances is presented in the table below.

Table 4: Comparison of Airline Alliance Groups Star Alliance, Oneworld and Skyteam

\begin{tabular}{|c|c|c|c|}
\hline Facility & Star Alliance & Oneworld & SkyTeam \\
\hline Incorporation date & 14 May 1997 & 1 February 1999 & 22 June 2000 \\
\hline Slogan & $\begin{array}{l}\text { The way the earth } \\
\text { connects }\end{array}$ & $\begin{array}{l}\text { Oneworld revolves } \\
\text { around you }\end{array}$ & Caring more about you \\
\hline Size & The largest one & The smallest one & $\begin{array}{l}\text { The youngest and } \\
\text { growing one }\end{array}$ \\
\hline Employees & 460238 & 317028 & 452590 \\
\hline Category & Global network & $\begin{array}{l}\text { Evenly spread } \\
\text { throughout the } \\
\text { world }\end{array}$ & $\begin{array}{l}\text { Very strong in the } \\
\text { European Union } \\
\text { countries }\end{array}$ \\
\hline Alliance members & 28 airlines & 13 airlines & 20 airlines \\
\hline Benefits & $\begin{array}{l}\text { e-ticketing } \\
\text { available }\end{array}$ & $\begin{array}{l}\text { First one to issue } \\
\text { interlining e-tickets }\end{array}$ & e-ticketing available \\
\hline Loyalty Programs & $\begin{array}{l}\text { Frequent flyer } \\
\text { programs available }\end{array}$ & $\begin{array}{l}\text { Frequent flyer } \\
\text { programs available }\end{array}$ & $\begin{array}{l}\text { Frequent flyer } \\
\text { programs available }\end{array}$ \\
\hline Performance & $\% 88,13$ & $\% 88$ & $\% 85,11$ \\
\hline Average delay in minutes & 13,73 & 13,48 & 17,63 \\
\hline Lounge & $1000+$ & $650+$ & $600+$ \\
\hline Passenger patronage & 727 million & 557 million & 665 million \\
\hline Countries services & 192 & 161 & 177 \\
\hline Destinations & 1330 & 1016 & 1062 \\
\hline Fleet size & 4657 & 3560 & 3054 \\
\hline Headquarters & Frankfurt & New York & Amsterdam \\
\hline Customer satisfaction & Excellent & Fair & Fair \\
\hline Annual revenue & 170 million $\$$ & 125 million $\$$ & 150 million $\$$ \\
\hline Daily flight & $18800+$ & 12750 & 16609 \\
\hline Market share (2016) & $\% 23,8$ & $\% 17,8$ & $\% 20,6$ \\
\hline
\end{tabular}

Source: Own representation by researching web sites of airline alliances.

According to Skytrax, the international aviation organization, Star Alliance has been the best airline alliance in 2017. Star Alliance has been voted the World's Best Airline 
Alliance for 2018 by travellers in the global passenger satisfaction survey, with Oneworld in 2nd place and SkyTeam in 3rd position (Skytrax,2018). Skytrax can rate up to five stars from a star as rating airline companies. While Skytrax is ranking the classification, it evaluates the qualifications of airline companies in terms of many criteria. These criteria include many qualities including seat comfort, in-flight entertainment, cabin cleanliness and condition, service quality, service efficiency and cabin safety standards (Skytrax, 2017). According to Li (2017), the Skytrax Global Airline Rating Program (1-5 stars) has a low reliability compared to airline companies' information on Twitter. Although Li presented these results, according to Skytrax that the 5-stars airline companies in Asia and the Middle East can be interpreted to be objective in spite of global powers in America and Europe. For example, According to Skytrax, Turkish Airlines has four stars. There are four "five stars" rating airlines in the Star Alliance association. There are eight "four stars" rating airlines; 15 airline companies have "three stars" rating.

According to Skytrax (2017); The 5-stars members of the Star Alliance, Skyteam and Oneworld alliances are as follows:

Table 5: The Origins of Five Star Airline Companies and their Alliances (Skytrax, 2017)

\begin{tabular}{|l|l|l|}
\hline 5 stars airlines & Origin & Alliance \\
\hline ANA All Nippon Airways & Asia & Star Alliance \\
\hline Asiana Airlines & Asia & Star Alliance \\
\hline Cathay Pacific Airways & Asia & Oneworld \\
\hline Etihad Airways & Middle East & No alliance \\
\hline EVA Air & Asia & Star Alliance \\
\hline Garuda Indonesia & Asia & Skyteam \\
\hline Hainan Airlines & Asia & No alliance \\
\hline Japan Airlines & Asia & Oneworld \\
\hline Lufthansa & Europa & Star Alliance \\
\hline Qatar Airways & Middle East & Oneworld \\
\hline Singapore Airlines & Asia & Star Alliance \\
\hline
\end{tabular}

When the data in this table are examined, it is noteworthy that there is no USA airline company. While 10 of the 5 stars airlines are of Middle Eastern and Asian origin, only 1 (Lufthansa) is of European origin. It is seen that the two-star airlines (Etihad and Hainan) are not members of any alliance. However, Etihad and Hainan aren't member of any alliance they have got five stars airlines award. As defined by Min \& Joo (2016) and Kottas \& Madas (2018) joining the alliance does not necessarily improve comparative activity efficiency for big airlines, but smaller alliances perform better than the larger one. 


\section{The world's top 10 airlines 2018}

1. Singapore Airlines

2. Qatar Airways

3. ANA All Nippon Airways

4. Emirates

5. Eva Air

6. Cathay Pacific Airways

7. Lufthansa

8. Hainan Airlines

9. Garuda Indonesia

10. Thai Airways

11.

\section{The world's best low-cost airlines 2018}

1. AirAsia

2. Norwegian

3. EasyJet

4. Jetstar Airways

5. AirAsia X

6. WestJet

7. IndiGo

8. Southwest Airlines

9. Eurowings

10. Scoot (Skytrax,2019)

It is noteworthy that the best low-cost airlines companies are not members of any airline alliances or are not accepted as members by alliances. Therefore, it can be said that; airline alliances are not low-cost airlines; alliance is a type of cooperation formed by airline companies offering full service.

\section{CONCLUSION}

Advances in technology, communication and transportation, along with economic, social and political developments in the world, have also affected the aviation sector. The competitive battle between businesses has also manifested itself in airline companies. In order to remain strong in this war, it has been necessary to create strategic alliances. 
In order to be successful in the international markets in the air transport sector, it is necessary to facilitate the needs of the customers and expand the range of services. Providing passengers with the opportunity to reach the destinations where they want at any time is a difficult task for a company that requires cost-effective, hardware-wide investments. Overcoming these challenges was possible by reducing costs, providing customer needs solely building strategic alliances.

The aims of Strategic alliances between airlines are entering new markets, sharing information technologies, reducing costs, reducing risk and competition. Airline alliances reduce the transfer and waiting times of the passengers traveling, expand the range by offering more flight alternatives, provide various prizes for frequent flying passengers, and provide advantages such as discount and booking priority. Thanks to the strategic alliances' practices, the company provides advantages such as high-quality service, shared training for the employees, common use of maintenance and repair points, and ease of change in spare parts.

Increasing demands on the airline sector leads to the growth of the airline market and the formation of harsh competition conditions. These competition conditions encourage airline companies to become partners and increase the quality of services. Competition conditions also reduce ticket prices.

The contribution of this study is representation of literature in alliances in various aspects. Major contribution of this study includes comparison of airline alliances and current situation of strategic airline alliances. This research presents comparison of three biggest alliances by evaluating studies in literature. This research presents the alliances to identify their relative positions in the industry. Moreover, this study can be base research for future scientific studies. In the study, the strategic cooperation types and advantages are presented and Star Alliance, Skyteam and Oneworld alliances are compared by creating a table and it is determined that Star Alliance is more preferred than the others in terms of the number of member companies and qualification. In addition, it was found that the 5-stars airlines were mostly in the Star Alliance according to the Skytrax rating agency. And it was determined that the airline companies, which are members of airline alliances, are also full-service airlines. Low-cost airline companies are not accepted as members of the alliance. When the groups of strategic collaborations were compared on sustainability, it was found that the Oneworld alliance took more concrete steps than others.

When alliances are compared in terms of the number of employees, fleet size (number of aircraft), number of destinations, annual number of passengers, annual income, number of daily flights, and number of countries served, it is seen that the Star Alliance is the most powerful one. In terms of customer satisfaction, Star Alliance can be evaluated excellent but Skyteam and Oneworld can be evaluated fair. Compared to the services offered in the three alliances; it is seen that all three of them offer the same services as frequent flyer ease and e-ticket opportunity. In addition Skyteam can be seen very strong in the European Union countries and the youngest one.

This study shows alliances' status tables which have never been encountered before. This study provides a basis current situation for comparison of strategic alliances in the aviation sector. The strategic cooperation of the airlines offers advantages; but also, it can cause the risk of monopolistic formation. This could mean expensive tickets for the passengers and 
the fact that they can doom to high prices. That is why; in future studies, the evaluation of the cooperation in the aviation sector for customers may be examined. Further analyses may concentrate on examining a bigger sample of companies of alliances, and also deeper analysis aiming on capital structure influences, and performance indicators.

\section{HAVAYOLU IŞLETMELERINDE STRATEJİK IŞ̧IIRLIKLERİ: SKYTEAM, ONEWORLD, STAR ALLIANCE GRUPLARININ KARŞILAŞTIRILMASI}

\section{GİRİŞ}

İkili veya çoklu anlaşmalar olarak görülen stratejik ortaklıklar; işletmelerin ortak amaç doğrultusunda hizmetlerini koordineli bir şekilde bir araya getirmeleri olarak görülebilir. Doganis (2006) çalışmasında ortak marka, servislerin standartlaşması, personel ve terminal kolaylıkları gibi bileşenlerinin stratejik ortaklıklar konusunda itici faktörler olduğunu belirtmiştir. Cravens ve diğerleri, (1993:55) stratejik bir ittifakı; çevresel türbülans ve çeşitlilik yüksek olduğunda; kuruluşun beceri ve kaynak boşlukları yüksek olduğunda; kuruluşun bir ürün veya pazarda rekabet avantajı kazanması için bir araç olarak tanımlamaktadır. Öte yandan, Spekman ve Sawhney (1990:90), stratejik bir ittifak1 "ortakların uzun vadeli işbirlikçi bir çaba ve ortak hedeflerine yönelik bireysel yönelimleri geliştirmeye yönelik önemli yatırımlar yapmaları” şeklinde bir işbirliğine dayalı bir ilişki türü olarak tanımlamıştır. Bu çalışmada, havacılık pazarında işbirliği türleri olarak bilinen kod paylaşımı, sık uçuş anlaşması, havuz anlaşması, ortaklık, blok rezervasyonu, ticari anlaşmalar, özel orantı anlaşması gibi konular açıklanacaktır. Havayolu sektörünün önde gelen stratejik işbirliği grupları arasında yer alan Skyteam, Star Alliance ve Oneworld ittifakları hakkında bilgi verilerek üç grubun karşılaştırması yapılacaktır.

\subsection{Literatür Özeti}

Bu bölümde stratejik ittifakların karşılaştırılması ile ilgili birkaç çalışma tartışılmıştır. Min \& Joo (2016) havayolu işindeki stratejik ittifakların performansını karşılaştırmıştır. Wang (2014), havayollarının, küresel bir havayolu ittifakına katılarak müşteri marka eşitliği ve marka tercihi algısını artırarak tüketici satın alma niyetini etkileyebileceğini belirtmiştir. Kottas ve Madas (2018), ittifak grubu üyeliğinin Veri Zarflama Analizi (DEA) uygulayarak üstün havayolu verimliliğiyle ilişkili olmadığını tespit etmişlerdir.

\subsection{Stratejik İşbirliği Uygulamaları}

Hava taşımacılığında farklı işbirliği düzenlemeleri kullanılarak sektörel gelişmelerin daha hızlı hale getirilmesi hedeflenmektedir. Havayolu şirketlerinde en yaygın işbirliği türleri kod paylaşımı, sık uçan yolcu, ortak girişim, havuz anlaşması ve pazarlama işbirliği yöntemleridir.

\section{ARAŞTIRMA YÖNTEMI}

$\mathrm{Bu}$ çalışmada betimsel araştırma yöntemi kullanılmıştır. Betimleyici araştırmalar çoğunlukla kesitsel araştırmalardır. Araştırmanın örneklemi Skyteam, Staralliance ve Oneworld üye şirketlerinden oluşmaktadır. Örnekleme dahil edilen havayolu işbirlikleri 
üyeleri olan havayolu şirketlerinin kurumsal web siteleri betimsel tarama modeliyle incelenmiştir. Tarama modeli; geçmişte ya da halen varolan bir durumu varolduğu şekliyle betimlemeyi amaçlayan araştırma yöntemidir. Araştırmaya konu olan olay, birey ya da nesne, kendi koşullan içinde ve olduğu gibi tanımlanmaya çalışılır (Karasar, 2007: 77).

\section{BULGULAR}

Global dağıtım sistemlerinin yaygınlaşması ve havayolu ulaştırma şirketleri için geliştirilen bilgisayarlı rezervasyon sistemlerinin kullanılması ile büyük ortaklık grupları oluşmuştur. Bu birleşme grupların en önemli ve göze çarpanları Star Alliance, Oneworld, Skyteam'dir. Star Alliance 1997 yılında kurulmuştur ve 28 üyesi vardır (Star Alliance, 2018). Oneworld işbirliği 1999 yılında kurulmuştur ve 15 üyesi vardır(Oneworld, 2018). Skyteam işbirliği 2000 yılında kurulmuş ve 20 havayolu işletmesi üyedir (Skyteam,2018). Çalışan sayısı, filo büyüklüğü (uçak sayısı), destinasyon sayısı, yıllık yolcu sayısı, yıllık gelir, günlük uçuş sayısı, hizmet verilen ülke sayısı bakımından kıyaslandığında Star Alliance ittifakının en güçlü durumda olduğu görülmektedir. Müşteri memnuniyeti bakımından da Star Alliance mükemmel notunu alarak en iyi durumda görülmektedir. Üç ittifak sunulan hizmetler bakımından kıyaslandığında ise; üçünün de sık uçuş yapan yolcu kolaylığı ve e-bilet imkanı gibi aynı hizmetleri sunduğu görülmektedir.

\section{SONUÇ}

Havayolu ulaşımı sektöründe uluslararası pazarlarda başarılı olabilmek için öncelikle müşterilerin işlerinin kolaylaştırılması hizmet yelpazesinin genişletilmesi gerekir. Yolculara istedikleri zaman istedikleri destinasyonlara ulaşma imkanlarının sağlanması bir firma için ekonomik anlamda maliyetli, donanım açısından kapsamlı yatırımları gerektiren zor bir iştir. Bu zorlukların aşılması, maliyetlerin düşürülmesi, müşteri ihtiyaçlarının karşılanması ancak stratejik işbirlikleri oluşturmakla mümkün olmuştur.

Bu çalışmada stratejik işbirliği türleri, avantajları ortaya konularak, Star Alliance, Skyteam ve Oneworld ittifakları tablo oluşturularak karşılaştırılmış ve Star Alliance'ın üye işletme sayısı ve nitelik bakımından diğerlerinden daha ileri seviyede olduğu belirlenmiştir. Ayrıca Skytrax derecelendirme kuruluşuna göre 5 yıldızlı olan havayolu işletmelerinin çoğunlukla Star Alliance ittifakında olduğu tespit edilmiştir. Ayrıca havayolu ittifaklarına üye olan havayolu şirketlerinin hepsinin de tam hizmet sağlayan havayolu şirketi olduğu ve düşük maliyetli havayolu işletmelerinin ittifaka üye olarak kabul edilmediği tespit edilmiştir. Sürdürülebilirlik konusunda stratejik işbirlikleri grupları karşılaştırıldığında Oneworld ittifakının diğerlerine göre daha somut adımlar attığı ortaya çıkmıştır.

Bu çalışma havacılık sektöründe faaliyet gösteren stratejik ittifakların karşılaştırılmasına bir temel oluşturmuştur. Havayollarının stratejik işbirliği yapmaları avantajlar sunarken monopolistik ve tekelci oluşum riski ortaya çıkarabilir. Bu durum yolcu açısından pahalı bilet ve sunulan hizmete eli mahkum durumda kalabilmesi anlamına gelebilir. Bundan dolayıdır ki; sonraki çalışmalarda havacılık sektöründeki işbirliklerinin müşteriler açısından değerlendirilmesi incelenebilir. 


\section{REFERENCES}

Airporthaber (2013), http://www.airporthaber.com/thy-haberleri/thyden-trafik-anlasmasi. html (retrieved from 25 Mayıs 2018)

Bose, I., \& Mugambi, P. (2017). Strategic Effectiveness of Selected organizations in UAE: Cases of Etihad Airways and Emirates NBD Bank. Globsyn Management Journal, 51. https://doi.org/10.1108/SD-12-2014-0168

Brekalo, L., \& Albers, S. (2016). Effective logistics alliance design and management. International Journal of Physical Distribution \& Logistics Management, 46(2), 212240. https://doi.org/10.1108/IJPDLM-08-2014-0201

Czipura, C., \& Jolly, D. R. (2007). Global airline alliances: sparking profitability for a troubled industry. Journal of business strategy, 28(2), 57-64. https://doi. org/10.1108/02756660710732666

Cole, G. A. (2004). Management theory and practice. Cengage Learning EMEA.

Cools, K., \& Roos, A. (2005). The Role of Alliances in Corporate Strategy. Boston, MA: Boston Consulting Group.

Çepni, S. (2010). Introduction to research and project work. Celepler Printing, Trabzon.

Dayınlarlı, K. (2007) Joint Venture Sözleşmesi, 3. Baskı, Ankara.

Earl, J., Martin, A., McCarthy, J. D., \& Soule, S. A. (2004). The use of newspaper data in the study of collective action. Annu. Rev. Sociol., 30, 65-80.

Elmuti, D., \& Kathawala, Y. (2001). An overview of strategic alliances, Management Decision, Vol. 39 Issue: 3, pp.205-218, https://doi.org/10.1108/ EUM0000000005452

Doganis, R. (2006). The Airline Business (2nd ed.). Routledge.

Evans, N. (2001). Collaborative strategy: an analysis of the changing world of international airline alliances. Tourism management, 22(3), 229-243.

FAA (2018), https://www.faa.gov/data_research/aviation_data_statistics/ (10 Mayıs 2018)

Grunow, J. (2012), The AA, BA, Iberia Joint Business: Challenges and Opportunities, Joint Business General Management Team, London.

Gudmundsson, S.V. (1999), Airline alliances: consumer and policy issue, European business Journal, Vol. 11 No. 3, pp. 139-45.

IATA (2018), https://www.iata.org/publications/pages/annual-review.aspx (01 Mayıs 2018)

İlarslan, K., Vurur, S. N., \& Biyıklı, F. (2014). An Empirical study for investigation of the effects of strategic alliances in the Civil Aviation sector: THY (Turkish Airlines) case. Mediterranean Journal of Social Sciences, 5(22), 102.

Karasar, N. (2007). Bilimsel araştırma yöntemi, 14. Baskı, Nobel Yayınları, Ankara. 
Kazakova, N., Shemetkova, O., Chemarina, A., \& Melnik, M. (2018). Analysis Of Effectiveness Of Companies Participation In International Strategic Alliances. International E-Journal of Advances in Social Sciences, 4(11), 221-228.

Kiraci, K. (2019). Does Joinıng Global Alliances Affect Aırlines’ Financial Performance? In Business \& Life Sciences, 39. IJOPEC Publication No: 2019/09

Klophaus, R., \& Lordan, O. (2018). Code sharing network vulnerability of global airline alliances. Transportation Research Part A: Policy and Practice, 111, 1-10. https://doi.org/10.1016/J.TRA.2018.02.010

Kottas, A. T., \& Madas, M. A. (2018). Comparative efficiency analysis of major international airlines using Data Envelopment Analysis: Exploring effects of alliance membership and other operational efficiency determinants. Journal of Air Transport Management, 70, 1-17.

Li, G. (2017). Application of Sentiment Analysis: Assessing the Reliability and Validity of The Global Airlines Rating Program (Bachelor's thesis, University of Twente).

Milton Glisson, L., Cunningham, W. A., Harris, J. R., \& Di Lorenzo-Aiss, J. (1996). Airline industry strategic alliances: marketing and policy implications. International Journal of Physical Distribution \& Logistics Management, 26(3), 26-34.

Min, H. \& Joo, S.-J. (2016). A comparative performance analysis of airline strategic alliances using data envelopment analysis. Journal of Air Transport Management. Volume 52, April 2016, Pages 99-110

Mühim, S. A. (2012). Şirket birleşmeleri (Mergers) ve havayolu şirketlerinde merger uygulamalarına örnekler (Doctoral dissertation, İstanbul Kültür Üniversitesi/Sosyal Bilimler Enstitüsü/İşletme Anabilim Dalı/İşletme Bilim Dali).

Oneworld (2018), https://www.oneworld.com/news-information (05 Haziran 2018)

O'rourke, K. H. and Williamson, J. G. (2002). When did globalisation begin? European Review of Economic History, 6(1), 23-50.

Rajasekar, J., \& Fouts, P. (2009). Strategic alliances as a competitive strategy: How domestic airlines use alliances for improving performance. International Journal of Commerce and Management, 19(2), 93-114. https://doi. org/10.1108/10569210910967860

Ratliff, R., \& Weatherford, L. R. (2013). Codeshare and alliance revenue management best practices: AGIFORS roundtable review. Journal of Revenue and Pricing Management, 12(1), 26-35.

Saglietto, L. (2009). Airline alliances: When competitiveness can be approached with specific social networks. Competitiveness Review: An International Business Journal, 19(4), 304-322. https://doi.org/10.1108/10595420910977425

Schweiger, D. M., \& Very, P. (2003). Creating value through merger and acquisition integration', Advances in Mergers and Acquisitions (Advances in Mergers \& 
Acquisitions, Volume 2).

Šimunović, S., Tatalović, M., \& Bajić, J. (2011, April). Global Airline Alliances in the Light of Economic Integrations-Croatia Airlines Challenges. In Proceedings of 8th International Conference «Economic Integration, Competition and Cooperation (pp. 6-9). http://dx.doi.org/10.213 9/ssrn.2232677

Skyteam (2018), https://www.skyteam.com/en (20 May1s 2018)

Skyteam (2006), The SkyTeam member airlines in collaboration with France (Ed.): available at: www.skyteam.com.

Skytrax (2017), https://skytraxratings.com/ (15 Mayıs 2018)

Spekman, R. E., \& Sawhney, K. (1990). Toward a conceptual understanding of the antecedents of strategic alliances. na.

Sobie, B. (2007). Never say never. Airline Business, 23(9), 63-64,67. Retrieved from https://search.proquest.com/docview/204167122? accountid $=15958$

Song, Y. A., Park, J. M., \& Cornejo, K. (2016). The Effect of a Firm's Resource Characteristics on Strategic Alliance Formation in the Airline Industry. Journal of International Trade \& Commerce, 12(5), 149-166.

Star Alliance (2018), https://www.staralliance.com/en/member-airlines (10 May1s 2018)

Steinhilber, S. (2008). Strategic Alliance: Three Ways to Make Them Work. Boston, MA: Harvard Business Press.

Sumer, H. (2003), Şirket Birleşmeleri, Alfa Yayınları, İstanbul

Tunahan, H., Esen, S., \& Takil, D. (2016). The Comparative Analysis of Financial Risk Level of Airlines Companies by Using Fuzzy Logic Method. Journal of Accounting, Finance and Auditing Studies, 2(2), 239.

Wang, S. W. (2014). Do global airline alliances influence the passenger's purchase decision? Journal of Air Transport Management, 37, 53-59. 


\begin{tabular}{|c|c|c|}
\hline $\begin{array}{l}\text { KATKI ORANI/ } \\
\text { CONTRIBUTION } \\
\text { RATE }\end{array}$ & $\begin{array}{l}\text { AÇIKLAMA/ } \\
\text { EXPLANATION }\end{array}$ & $\begin{array}{c}\text { KATKIDA } \\
\text { BULUNAN/ } \\
\text { CONTRIBUTOR }\end{array}$ \\
\hline $\begin{array}{l}\text { Fikir veya Kavram/Idea } \\
\text { or Notion }\end{array}$ & $\begin{array}{c}\text { Araştırma hipotezini veya fikrini } \\
\text { oluşturmak / Form the research } \\
\text { hypothesis or idea }\end{array}$ & $\begin{array}{l}\text { Sabiha ANNAÇ } \\
\text { GÖV }\end{array}$ \\
\hline Tasarım/Design & $\begin{array}{l}\text { Yöntemi, ölçeği ve deseni tasarlamak/ } \\
\text { Designing method, scale and pattern }\end{array}$ & $\begin{array}{c}\text { Sabiha ANNAÇ } \\
\text { GÖV }\end{array}$ \\
\hline $\begin{array}{c}\text { Veri Toplama ve İşleme/ } \\
\text { Data Collecting and } \\
\text { Processing }\end{array}$ & $\begin{array}{l}\text { Verileri toplamak, düzenlenmek ve } \\
\text { raporlamak/Collecting, organizing } \\
\text { and reporting data }\end{array}$ & $\begin{array}{l}\text { Sabiha ANNAÇ } \\
\text { GÖV }\end{array}$ \\
\hline $\begin{array}{l}\text { Tartişma ve Yorum/ } \\
\text { Discussion and } \\
\text { Interpretation }\end{array}$ & $\begin{array}{l}\text { Bulguların değerlendirilmesinde ve } \\
\text { sonuçlandırılmasında sorumluluk } \\
\text { almak/Taking responsibility in } \\
\text { evaluating and finalizing the findings }\end{array}$ & $\begin{array}{l}\text { Sabiha ANNAÇ } \\
\text { GÖV }\end{array}$ \\
\hline $\begin{array}{l}\text { Literatür Taramas1/ } \\
\text { Literature Review }\end{array}$ & $\begin{array}{c}\text { Çalışma için gerekli literatürü } \\
\text { taramak/ Review the literature } \\
\text { required for the study }\end{array}$ & $\begin{array}{c}\text { Sabiha ANNAÇ } \\
\text { GÖV }\end{array}$ \\
\hline
\end{tabular}

